\section{From Manhattan to Los Alamos}

The National Labs: Science in an American System 1947-1974

by Peter J. Westwick

Harvard University Press: 2003. 384 pp.

$\$ 51.50, £ 33.50$

\section{Herbert York}

The National Laboratories are a group of ten research and development institutions, sponsored and largely funded by the US Department of Energy and managed in a style known as GOCO: government-owned, contractor-operated. The individual labs employ up to 10,000 people, including scientists and engineers from a wide range of disciplines, and have annual operating costs ranging from a few hundred million dollars to more than $\$ 1$ billion. People who are able - and rash enough - to make such judgements believe that two them, Los Alamos and Lawrence Livermore, are, in whatever order, perhaps the two best laboratories in the world.

The laboratories have a common root in the Manhattan Project in the Second World War. The project was set up to exploit the newly discovered process of nuclear fission with a view to developing an atomic bomb. The immediate purpose of this, in turn, was to bring about a quick and decisive end to the deadly series of wars that had plagued the world since 1914. The project was directed and funded by the US Army Engineer Corps and implemented by several separate contractors, including pre-existing university laboratories at Berkeley, Chicago, Columbia and Ames; newly created labs at Los Alamos and Clinton; and totally new production facilities of unprecedented size, built and operated by large private companies at Oak Ridge and Hanford.

After a general demobilization and a brief hesitation, growing concerns about the Cold War led to a decision to continue with the development of nuclear weapons under the management and direction of a new civilianled government agency, the Atomic Energy Commission. The programme was quickly expanded to include the development and operation of giant particle accelerators, commercial power reactors, and research in biology and medicine. Most of it was done in facilities adapted or built for the wartime project, but some new laboratories, notably Brookhaven and Argonne, were established in the late 1940s.

The intensifying Cold War led to new thinking about what the United States really needed, and the labs were quick to recognize and exploit new opportunities. These factors stimulated them to evolve and expand, something they have done almost continu-

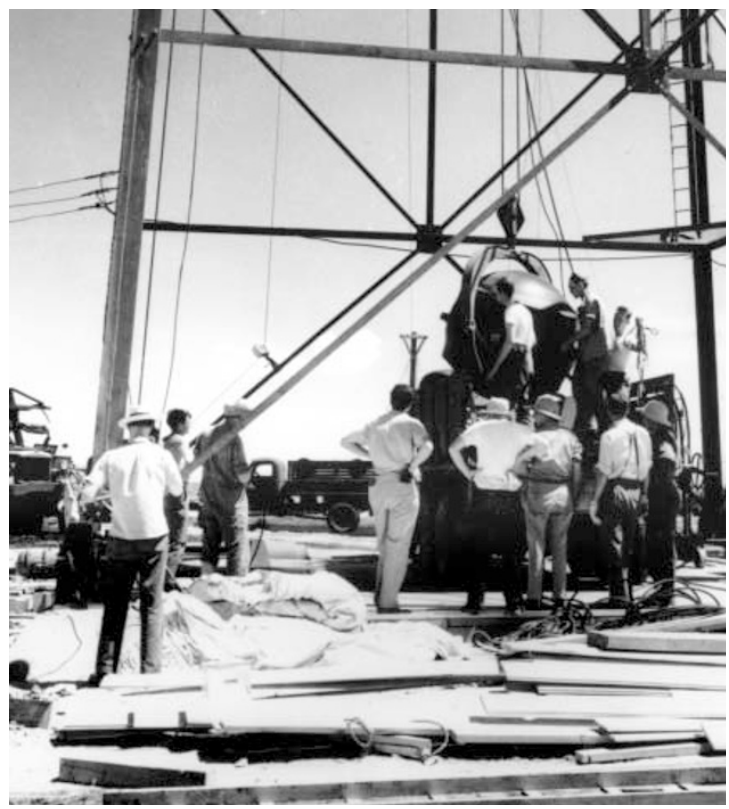

Brave new world: work on the Manhattan Project to make the atomic bomb led to the first National Laboratories.

ously ever since. Some programmes have been discarded along the way (nuclear propulsion for aircraft, ramjets and rockets among them), but many more new ones have been instituted. These include the construction and operation of new accelerators and 'advanced' light sources; work on nuclear fusion and other potential sources of energy; energy conservation; environmental studies; huge lasers for fusion and isotope separation; unraveling of the human genome; the development of new methods for gathering and analysing intelligence on foreign weapons programmes; and the creation of a variety of means for coping with weapons of mass destruction in the context of terrorism.

The laboratories have also been major drivers in the development of modern computers by being extremely demanding customers with lots of money and smart people. In effect, they subsidized the exuberant expansion of the US computer industry and the resulting enormous computational capability that the world now enjoys.

In addition to their obvious contributions to national security and economic development, the labs played other less well known but nonetheless important roles in the international arena. International cooperation in basic science comes as no surprise, but there has even been close cooperation in the area of weapons development and related technologies. The working relationship with British weapon designers that existed during the war years was revived, with some limitations, in the 1950s. Parallel but more guarded cooperation with the French dates from the 1960s. And when the Cold War ended, US and Russian weapons laboratories began a major two-way programme of exchanges and visits. A similar, although smaller and more tightly circumscribed, relationship also exists with Chinese weaponeers.

Westwick describes these events clearly, accurately and (mostly) comprehensively. There are other books on individual labs, but this is the only one that pulls them all together. Historians of science and of the Cold War, as well as all students of bureaucracy, will find this book useful, and staff and alumni of the system - by now a very large audience - will find it an enjoyable read.

One of Westwick's main points is that the interactions between the labs and with the government produced a system that is much more than the sum of its component parts. The labs simultaneously compete and cooperate with each other. The government micromanages the labs, while allowing them remarkable freedom and flexibility in some areas. The core programme of each laboratory is highly specialized but is surrounded by many other broadly based activities. Westwick coins the term 'systemicity' to describe these processes and their results.

As well as the direct impact of their programmes, the labs have also strongly influenced the course of national and world events in ways not covered in the book. These include lab alumni who served as high-level officials. Two have been cabinet members Harold Brown was defence secretary, and Glenn Seaborg was chairman of the Atomic Energy Commission - and several dozen more have filled influential and authoritative positions in national government departments, or served as US representatives to international organizations such as NATO and the United Nations. Many others employees as well as alumni - have participated in high-level advisory committees dealing with national security, including arms control and intelligence.

Finally, many of the best-known alumni have been key participants in public-interest groups, including those engaged in peace activism. The international Pugwash movement was founded largely by veterans of the Manhattan Project. At the national level, two peace and disarmament advocacy groups (the Federation of American Scientists and the Council for a Livable World) were founded by alumni, and a constant stream of lab personnel and alumni have testified before the Congress, both in support of and in opposition to government policies and decisions.

Herbert York is director emeritus of the Institute on Global Conflict and Cooperation,

University of California, San Diego, La Jolla, California 92093, USA. 